\title{
Study on the Relationship of Trademark Portfolio and Enterprise Performance in China
}

\author{
Yangao Xiao \\ University of Electronic Science and Technology \\ Chengdu, China \\ Kaiyue Kang \\ University of Electronic Science and Technology \\ Chengdu, China
}

\author{
Huaqing Ran* \\ Chengdu College of Arts and Sciences \\ Chengdu, China \\ *Corresponding author
}

\author{
Ao $\mathrm{Yu}$ \\ University of Electronic Science and Technology \\ Chengdu, China
}

\begin{abstract}
Since 2002, the number of registered trademark applications in China has consistently ranked first in the world. However, some scholars questioned whether massively registered trademarks had significant positive influences on enterprise competitiveness. From the perspective of trademark layout of enterprise brand strategy, this paper opens the "black box" for trademark and business, and constructs the concept model of trademark portfolio. On this basis, data from 241 listed companies in different regions in China (including 9,824 consolidated subsidiaries) were collected, and empirical analysis was conducted on the correlation between different trademark portfolios and corporate performance. The research results show that there are significant differences in the correlation between different trademark portfolios and enterprise performance (including operating income and operating profit margin). In particular, there is a $\mathrm{U}$-shaped relationship between the main trademark portfolio of non-main business and operating profit margin; the non-main trademark portfolio of non-main business is positively related to operating income, but not related to operating profit margin. The above research conclusions to a certain extent explain the inherent logic of the continuous increase in the number of trademark registration applications in China, and have an enlightening significance for enterprises to carry out trademark layout.
\end{abstract}

Keywords-trademark portfolio; enterprise performance; relationship; China

\section{INTRODUCTION}

After 40 years of continuous reform and opening up, China has developed into the world's second largest economy. At the same time, the number of Chinese trademark registration applications has been blowout phenomenon. Since 2002, domestic and foreign applicants have registered the number of registered trademark applications in China for 16 years in a row. The average annual growth rate of the total applications is $8.51 \%$. In this connection, some scholars questioned the rationality of the rapid increase in the number of Chinese trademark registration applications. Nguyen (2016) considered that China's newly promulgated trademark law (2013) was to safeguard China's status as a global trademark factory, the new law would motivate the Chinese team's dedication and infatuation based on indicators, not to benefit Chinese brands and not to satisfy China's national economic growth. Dresden (2017) also held a similar view. He believed that once a trademark was registered in China, it would be difficult to revoke it for malicious purposes. Therefore, it will encourage trademark squatters to apply for more trademarks "in accordance with regulations" and legitimate trademark holders to apply for trademarks that far exceed their business category.

So, how to comprehensively and objectively analyze and evaluate the fact that the registered trademark of Chinese enterprises is so large? To answer this question, this paper creatively develops the concept model of trademark portfolio, and then uses the data of Chinese listed companies to do empirical research. The rest of this paper is organized as follows. Section 2 summarizes the literature on the value of trademarks and enterprise performance, and proposes a research framework, which contains our proposed portfolio model and eight assumptions. Section 3 is related to research methods, including data and sample collection and demonstration methods. Section 4 is the result of the research and a reasonable explanation of the research results. Section 5 concludes.

\section{LITERATURE REVIEW AND RESEARCH FRAMEWORK}

\section{A. Literature Review}

1) Value of trademark: According to WIPO, a trademark is a sign capable of distinguishing the goods or services of one enterprise from those of other enterprises. Trademarks are protected by intellectual property rights ${ }^{1}$.

The understanding of the value of a trademark has gone through a process from instrument method to value theory. Since the Middle Ages, trademarks have only been used as a mark of ownership and business order management tools(Wilkins, 2006). Before and after the industrial revolution,

https://enterprisefinanceinstitute.com/resources/knowledge/valuatio n/economic-value-added-eva/ 
the rise of the market and the promotion of merchant interest groups completely changed the course of trademark development and the value of trademark property was increasingly displayed (Freeman and Soete,1997). Under the guidance of labor theory, British and American courts realized that "Trademark use creates value" and trademarks can be protected as property. Then, the registration system becomes the key to the protection of the property of the trademark (Besen and Raskind, 1991). If the trademark is registered, it will become the property listed on the registration certificate from the moment it is issued. The emergence of Anti-Dilution Legislation shows that the focus of the court is not whether the consumer has been cheated, but rather to focus the judgment on the property value of the trademark itself. The loosening of trademark transfer and licensing further reflects the market's recognition of trademark property (Zhang, 2016).

After that, scholars argued how to protect a trademark in order to realize the value of a trademark. Zheng (1998) realized that the legal strength of a protected trademark should be proportional to the distinctiveness and popularity of the trademark. Originally trademarks were legally protected only within the scope of their registered goods, but if they were well-known trademarks, they could even be protected across categories. Barnes (2006) demonstrated the shortcomings of the current trademark law system from the perspective of the private and public nature of trademarks, and the value of legal protection of trademarks should be considered from the perspective of public interests. Mace (2017) believed that trademark protection has different degrees of impact on enterprise profits, values, and strategies.

The relationship between trademarks and brands are focused on, too. American marketing association (AMA) defines brand as a name, proper nouns, sign, or involving the combination of the above elements, which used to identify a seller or group of sellers of goods and services, and make them to separate goods and services with its competitors (Datta et al.,2017). Keller (2003) believes that the key to creating a brand is to choose names, logos, symbols, packaging designs, or other attributes that help identify and differentiate products from other products, which creates a combination of trademarks and brands. Ishan et al. (2015) demonstrated the value of trademarks by means of "brand-product matrix", the relationship between the brand and product sold by the enterprise. Crass et al. (2016) demonstrated the influence of trademark application on brand.

At present, more scholars analyze the value of trademarks from the perspective of the relationship between trademarks and enterprise performance and how to evaluate trademarks. Smith and Richey (2013) used three methods to evaluate the value of a trademark: cost method, market method and income method. Ishan and Noordin (2015) highlighted the benefits of adopting the income approach for enterprises, particularly the profit split method. In addition, more and more scholars study the value of trademarks from the relationship between trademarks and enterprise performance. Heathet al (2012) pointed out that there is a significant relationship between earnings and trademarks value, meaning that those enterprises with higher trademark value were the ones with higher profit. Block et al. (2014) showed that the number and breadth of trademark applications have inverted U-shaped relationships with the financial valuations of start-ups by valuations of venture capitalists (VCs). The findings also indicate that in later funding rounds, the value of trademark applications decreases when the start-up progresses into more advanced development stages.

2) Enterprise performance: Enterprise performance refers to the operating efficiency of an enterprise during a certain period of operation. The level of enterprise operating efficiency is mainly reflected in the enterprise's profitability, asset operating level, solvency and subsequent development capabilities. Enterprise performance evaluation has always been a research field that has attracted much attention. Performance evaluation was produced in the late 1930s. In 1939, Kesner of the United States first studied the relationship between American managers' compensation and performance evaluation (Aggarwal \& Samwick,2002).In the 1950s, Modigliani and Miller(1958) proposed the MM capital structure theory and studied the relationship between capital structure and enterprise value in a rigorous and scientific way. Since then, research on enterprise performance and evaluation has gradually increased. In 1992, Kaplan and Norton (1992) published an paper in the Harvard Business Review entitled "The Balanced Scorecard: Measures that Drive Performance". The idea of the Balanced Scorecard (BSC) is proposed: to divide the various factors concerning the appearance of the enterprise's surface and its deep realities, short-term results and long-term development, internal conditions and the external environment into several major aspects. And for various aspects of the objectives, design the corresponding evaluation indicators, in order to systematically and comprehensively reflect the enterprise's overall operations, for the enterprise's strategic management services. Fitzgerald(1993) proposed a multi-faceted analysis in 1993 and advocated evaluating enterprise performance in terms of finance, competition, service quality, innovation, flexibility, and resource utilization. Ness and Cucuzza (1995)proposed the ABC (Process Cost Based Process Evaluation) method in 1995. Since then, the enterprise performance evaluation model has been continuously innovating and developing, considering various factors such as strategy, time, quality, and product.

In China, the State-Owned Assets Supervision and Administration Commission of the State Council issued the "Guiding Opinions on Further Strengthening the Performance Evaluation of Central Enterprises(2009)" and recommended Economic Value Added (EVA), 360-Degree Feedback Evaluation, and Key Performance Indicators (KPI) and other enterprise performance assessment methods. Of the above four indicators of enterprise performance, EVA and KPI are inseparable from the enterprise's financial performance. The BSC and "360-degree feedback evaluation" can only be selected by the enterprise itself according to the enterprise's own situation. It is difficult for the public to conduct accurate analysis based on the disclosed public information. Therefore, 
at present, financial indicators are still the main indicators for scholars to study enterprise performance.

\section{B. Research Framework}

1) Model of trademark portfolio: This paper considers that since the trademark is the carrier and indispensable element of the enterprise brand, the choice of the trademark will affect the competitiveness of the enterprise(Xiao,2010). However, how should enterprises choose the trademark to be registered and the range of goods and services to which the registered trademark applies? In other words, what exactly should enterprises do with trademark portfolio? This paper develops the concept model of trademark portfolio according to the legal guidelines for trademark portfolio.

- 1) Trademark logo portfolio. As the choice of trademark logo will directly determine the scope of protection of trademark rights. Most national trademark laws stipulate that when an applicant applies for registration of a trademark, it is necessary to apply for a specific trademark logo and its corresponding product and service (Stuart Graham et.al,2013). And according to the provisions of the Trademark Law of China(2013), any sign that distinguishes a product of a natural person, legal person or other organization from other people's merchandise, including words, figures, letters, numbers, three-dimensional signs, color combinations, etc., as well as any combination thereof, can be registered as a trademark. Therefore, this paper divides the trademarks into main trademarks and non-main trademarks according to the degree of association between the trademark logo and the business scope of the enterprise and the frequency with which the enterprise uses the trademark logo.

- 2) Choice of the scope of trademark registration of goods and services. Each applicant must clearly and concisely describe the scope of the goods and services for which the trademark registration is applied for. The USPTO Acceptable Identification of Goods and Services Manual contains a detailed listing of acceptable goods and services identification (Wim Alberts, 2015). According to the provisions of the "Trademark Law" of China (2013), an applicant for trademark registration should fill in the product category and product name of the trademark in accordance with the stipulated commodity classification form. Therefore, this paper classifies the scope of goods and services for trademark registration into main business and non-main business, based on the type of goods and services used by the enterprise's registered goods and its relationship with the business

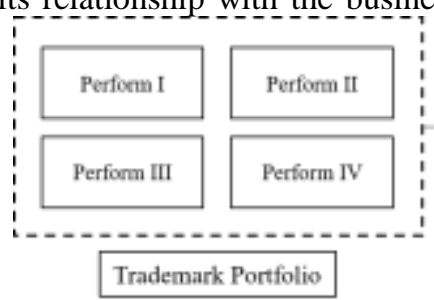

units of the enterprise. The structure of the trademark portfolio is shown in Figure 1.Thereinto, Portfolio I means main trademarks registered in main business. Portfolio II means main trademarks registered in nonmain business. Portfolio III means non-main trademarks registered in main business. Portfolio IV means non-main trademarks registered in non-main business.

\begin{tabular}{c|c|c|}
\cline { 2 - 3 } Non-main Trademark & PIII & PIV \\
\cline { 2 - 3 } Main Trademark & PI & PII \\
\cline { 2 - 3 } & \multicolumn{2}{|c|}{ Main Business Non-main Business }
\end{tabular}

Fig. 1. The structure of trademark portfolio.

2) Relationship between trademark portfolio and enterprise performance: As analyzed in 2), currently the data collected by scholars from publicly disclosed information is mainly enterprise financial data. In addition, the evaluation of brand competitiveness (Mortanges and Riel,2003) and trademark value (Chen et.al, 2005) is mainly evaluated from three aspects: financial indicators, market indicators and consumer indicators. Interbrand method, for example, uses financial analysis to evaluate the residual earnings of product or business, which refers to the balance of the future income from the product or business minus the revenue from the tangible assets (Huang, 2015). Therefore, when measuring enterprise performance, this paper still uses enterprise financial indicators as an indicator of enterprise performance.

The types of indicators commonly used in financial analysis and evaluation include profitability indicators (Zubarev I.S., 2017), solvency indicators(Chiriac,2015), operating capability indicators (Newey and Zahra,2009), growth capacity (Bergh and Verbruggen,1999) indicators, cash ability indicators(Mills,1998), and social contribution indicators. Most of the above index systems relate to the economic scale and economic efficiency of enterprises. And because a portfolio of trademarks can help enterprises determine which trademarks need to be applied to which products, the portfolio of trademarks determines the boundaries (amounts) of the goods to which the trademark applies and how different trademarks are applied to different products (efficiency)(Keller,2011). Therefore, this paper chooses financial indicators that measure enterprise performance from both the scale and efficiency elements. The conceptual framework of the research is developed as shown in "Fig. 2".

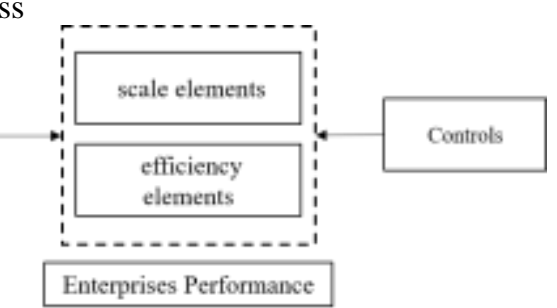

Fig. 2. Conceptual framework of the research. 
Based on the above analysis, this paper hypothesizes as follows:

H1: Trademark portfolio (PI PII PIII PIV) has a positive correlation to the scale elements

Why do enterprises have multiple trademarks in the same or different types of products? The first reason is related to market coverage. Procter \& Gamble is adopting a multitrademark (brand) strategy to significantly increase its market size. Therefore, this paper assumes that trademark portfolio has a positive correlation to the scale elements.

H2: Trademark portfolio (PI PII PIII PIV) has a positive correlation to the efficiency elements

The trademark portfolio includes all trademarks registered by an enterprise in the same or different business areas. Because the enterprise's different target markets have different preferences for a certain trademark, it is necessary for enterprises to adopt multiple trademark combinations. The multi-trademark combination encourages enterprises to pursue different price segments, different distribution channels, and different geographical divisions to maximize operating efficiency. Therefore, this paper assumes that trademark portfolio has a positive correlation to the efficiency elements.

\section{METHODS}

\section{A. Samples and Data}

1) Samples: This paper selects enterprise samples based on the following considerations. First, to ensure the universality of the data, the selected enterprises are located in the east, west, south, north, and middle cities of China which are Beijing, Tianjin, Shanghai, Hangzhou, Guangzhou, Shenzhen, Wuhan, Changsha, Xi'an and Chengdu. Secondly, in order to ensure that the selected data has a high degree of credibility and the necessary amount, this paper has selected 30 listed companies in each city, and removed those with incomplete data. At last, 241 listed companies were collected. Third, since the statistics of listed companies' economic indicators (financial indicators) is based on the statistics of listed companies and their consolidated subsidiaries, this paper has verified and collected 9804 consolidated subsidiaries of listed companies (according to the Annual Report of Listed Companies in 2016, and excluding the enterprise name or residence is a foreign or Hong Kong enterprise). So the final number of enterprises in this statistics is 10045 . The number and distribution of enterprises are shown in "Table II".

TABLE I. STATISTICS OF LISTED COMPANIES AND CONSOLIDATED SUBSIDIARIES IN 10 CITIES

\begin{tabular}{|c|l|l|l|}
\hline NO. & \multicolumn{1}{|c|}{ City } & $\begin{array}{c}\text { The number } \\
\text { of listed } \\
\text { companies }\end{array}$ & $\begin{array}{c}\text { Total number of } \\
\text { consolidated } \\
\text { subsidiaries }\end{array}$ \\
\hline $\boldsymbol{1}$ & Beijing & 26 & 686 \\
\hline $\boldsymbol{2}$ & Tianjin & 24 & 498 \\
\hline $\mathbf{3}$ & Shanghai & 26 & 1412 \\
\hline $\mathbf{4}$ & Hangzhou & 25 & 720 \\
\hline $\mathbf{5}$ & Guangzhou & 25 & 1526 \\
\hline $\boldsymbol{6}$ & Shenzhen & 27 & 2501 \\
\hline $\mathbf{7}$ & Wuhan & 22 & 757 \\
\hline $\boldsymbol{8}$ & Changsha & 25 & 631 \\
\hline $\boldsymbol{9}$ & Xi'an & 22 & 513 \\
\hline $\mathbf{1 0}$ & Chengdu & 19 & 560 \\
\hline Total & & 241 & 9804 \\
\hline
\end{tabular}

2) Collection of trademark data: First, according to the data released by the Trademark Office of the State Administration for Industry and Commerce of China, the registered trademarks of 10045 enterprises were collected. And, this paper further categorizes the trademarks of each company according to the legitimate criteria, i.e. each registered trademark's logo corresponds to each product or service category. Second, the main trademark is determined according to the logo of each enterprise's official website. Once the main trademark is determined, the data of the nonmain trademark is the total number of registered trademarks of the enterprise minus the number of the main trademark of that. Third, the main business is determined based on the enterprise's introduction and main products and services in the enterprise's official website. The business other than the main business is the non-main business.

Since the data of the enterprise trademark registration announced by the Trademark Office of the State Administration for Industry and Commerce is the registered trademark identification and the corresponding goods and services category, not the category of the registered trademark identification and business operations, this paper reclassifies the enterprise's main business and non-main business based on the Distinction Table for Similar Products and Services (2017 Text). That is, the main business and non-main business respectively correspond to the category of trademark registration goods and services, so that the authoritative data published by the country can be fully applied. The final data of the trademark portfolio is shown in "Table III".

TABLE II. STATISTICS OF REGISTERED TRADEMARKS

\begin{tabular}{|c|l|l|l|l|l|l|l|}
\hline City & $\begin{array}{c}\text { Number of } \\
\text { listed } \\
\text { companies }\end{array}$ & $\begin{array}{c}\text { Number of } \\
\text { Consolidated } \\
\text { company }\end{array}$ & $\begin{array}{c}\text { Total number } \\
\text { of registered } \\
\text { trademarks }\end{array}$ & $\begin{array}{c}\text { Number of } \\
\text { PI }\end{array}$ & $\begin{array}{c}\text { Number } \\
\text { of PII }\end{array}$ & $\begin{array}{c}\text { Number } \\
\text { of PIII }\end{array}$ & $\begin{array}{c}\text { Number of } \\
\text { PIV }\end{array}$ \\
\hline Beijing & 26 & 686 & 14386 & 278 & 3295 & 2703 \\
\hline Tianjin & 24 & 498 & 2515 & 151 & 389 & 1188 & 787 \\
\hline Shanghai & 26 & 1432 & 12283 & 520 & 2412 & 3093 & 6258 \\
\hline Hangzhou & 25 & 720 & 3704 & 308 & 1336 & 876 \\
\hline Guangzhou & 25 & 1526 & 11751 & 229 & 2216 & 1661 & 7645 \\
\hline Shenzhen & 27 & 2501 & 14376 & 420 & 2269 & 2552 \\
\hline Wuhan & 22 & 757 & 6711 & 106 & 566 & 1026 & 2004 \\
\hline Changsha & 25 & 631 & 464 & 1111 & 1743 \\
\hline
\end{tabular}




\begin{tabular}{|c|l|l|l|l|l|l|l|}
\hline City & $\begin{array}{c}\text { Number of } \\
\text { listed } \\
\text { companies }\end{array}$ & $\begin{array}{c}\text { Number of } \\
\text { Consolidated } \\
\text { company }\end{array}$ & $\begin{array}{c}\text { Total number } \\
\text { of registered } \\
\text { trademarks }\end{array}$ & $\begin{array}{c}\text { Number of } \\
\text { PI }\end{array}$ & $\begin{array}{c}\text { Number } \\
\text { of PII }\end{array}$ & $\begin{array}{c}\text { Number } \\
\text { of PIII }\end{array}$ & $\begin{array}{c}\text { Number of } \\
\text { PIV }\end{array}$ \\
\hline Xi'an & 22 & 513 & 2465 & 293 & 665 & 577 & 930 \\
\hline Chengdu & 19 & 560 & 4235 & 258 & 514 & 1798 & 1665 \\
\hline Total & 241 & 9804 & 76128 & 3027 & 14773 & 17217 & 41115 \\
\hline
\end{tabular}

\section{B. Methods}

\section{1) Dependent variables}

- Scale elements. This paper selects operating income as an indicator of "quantity" of enterprise performance. Because operating income largely measures the status and development level of an enterprise (Liang and Tian,2016). And in China, operating income, as an indicator of the scale of the economy, plays an important role in national economic accounting(Wan and $\mathrm{Qu}, 2012)$. In addition, information disclosure form and format of publicly issued securities issued by China Securities Regulatory Commission Standard No. 2 Content and Format of the Annual Report (Revised in 2017) also placed particular emphasis on the disclosure of operating income and income structure by listed companies. Especially, considering the time-lagged profitability after implement of enterprise strategy, this paper chooses the average operating income of 20142016 as the indicator of scale elements.

- Efficiency elements. Financial statement analysis experts claimed that operating profit margin is one of the indicators for evaluating profitability when performing financial analysis (Fairfield and Yohn, 2001; Patten et.al, 2014; Muhammad, 2016).This paper chooses operating profit margin to measure the enterprise's financial performance (operating income divided by sales), and also chooses the average operating profit margin of 2014-2016 as the indicator of efficiency elements.

2) Independent variable: trademark portfolio: According to whether the registered trademark is the main or non-main trademark and the scope of application of the registered trademark is the main business or non-main business, this paper has divided the trademark into four Portfolio. Main trademarks registered in the main business are categorized into Portfolio I. Main trademarks registered in the non-main business are categorized into Portfolio II. Non-main trademarks registered in the main business are categorized into Portfolio III. Non-main trademarks registered in the nonmain business are categorized into Portfolio IV. This paper not only considers the number of four types of trademark combinations but also the relationship between the four types of trademark portfolio. Portfolio I \%, Portfolio II \%, Portfolio III \%, Portfolio IV\% are the proportion of the total number of each kind. The absolute quantitative indicators(Portfolio I-IV) are used to analyze operating income. The relative quantitative indicators (Portfolio I \%-IV \%) are used to analyze operating profits margin.

3) Control variables: This paper uses several control variables that could have confounding effects on enterprises' scale and efficiency. First, this paper controls total asset, as enterprises with a lot of assets are likely to have higher performance, and this paper uses the logarithm of the total assets in order to reduce the impact of magnitude difference. Second, this paper controls debt asset ratio, because the debt asset ratio of enterprises also has a considerably impact on enterprise performance. Third, due to the establishment time of the enterprise can affect the enterprise development, this paper controls the age of enterprise. All the variables above all used the statistics of the average of 2014-2016.

TABLE III. THE DEFINITION OF VARIABLES

\begin{tabular}{ll}
\hline & Variable definition table \\
\hline $\begin{array}{l}\text { Scale Elements } \\
\text { Efficiency Elements } \\
\text { Controlled variable }\end{array}$ & $\begin{array}{l}\text { Dependent variable } \\
\text { = } \text { On (operating income) }\end{array}$ \\
$\begin{array}{l}\text { Debt Asset ratio } \\
\text { Ln total assets }\end{array}$ & $=$ Total debt/Total asset \\
Age & $=$ ln (total assets) \\
Independent variable & \\
Portfolio I & Main trademarks registered in main business \\
Portfolio II & Main trademarks registered in non-main business \\
Portfolio III & Non-main trademarks registered in main business \\
Portfolio IV & Non-main trademarks registered in non-main \\
& business \\
Portfolio I \% & Portfolio I \% = Portfolio I /Total Portfolio \\
Portfolio II \% & Portfolio II \% = Portfolio I /Total Portfolio \\
Portfolio III \% & Portfolio III \% = Portfolio I /Total Portfolio \\
Portfolio IV \% & Portfolio IV \% = Portfolio I /Total Portfolio \\
\hline
\end{tabular}

\section{Analysis and Results}

"Table IV" reports means, standard deviations, and correlation coefficients for all variables used in our analyses. For Portfolio I, Portfolio II, Portfolio II and Portfolio IV, the ratio of means is approximately 1:5:6:13. For Portfolio I \%, Portfolio II $\%$, Portfolio II $\%$, Portfolio IV $\%$, the ratio of means is approximately $1: 2: 2: 3$. This indicates the difference between quantity and composition. 
TABLE IV. MEANS, STANDARD DEVIATION AND CORRELATION OF VARIABLES

\begin{tabular}{|c|c|c|c|c|c|c|c|c|c|c|c|c|c|c|c|}
\hline & Mean & S.D. & 1 & 2 & 3 & 4 & 5 & 6 & 7 & 8 & 9 & 10 & 11 & 12 & 13 \\
\hline 1.Ln OI & 586.95 & 2038.51 & 1 & & & & & & & & & & & & \\
\hline $2 . O P R$ & 0.11 & 0.18 & 0.038 & 1 & & & & & & & & & & & \\
\hline 3.Portfolio I & 12.79 & 13.68 & 0.088 & -0.110 & 1 & & & & & & & & & & \\
\hline $\begin{array}{c}\text { 4.Portfolio } \\
\text { II }\end{array}$ & 62.45 & 102.05 & $0.233^{\text {** }}$ & 0.004 & $0.381^{* *}$ & 1 & & & & & & & & & \\
\hline $\begin{array}{c}\text { 5.Portfolio } \\
\text { III }\end{array}$ & 72.38 & 115.66 & $0.249^{* * *}$ & 0.049 & $0.455^{* * *}$ & $0.268^{* *}$ & 1 & & & & & & & & \\
\hline $\begin{array}{c}\text { 6.Portfolio } \\
\text { IIII }\end{array}$ & 161.12 & 307.38 & $0.369^{* *}$ & 0.038 & $0.362^{* *}$ & $0.589^{* *}$ & $0.633^{* *}$ & 1 & & & & & & & \\
\hline $\begin{array}{c}\text { 7.Portfolio } \\
\text { I \% } \\
\end{array}$ & 0.12 & 0.15 & $-{ }^{-} .144^{*}$ & -0.124 & -0.039 & $\begin{array}{l}- \\
0.282^{* *}\end{array}$ & $\begin{array}{l}- \\
0.305^{* *}\end{array}$ & $\begin{array}{l}- \\
0.314^{* * *}\end{array}$ & 1 & & & & & & \\
\hline $\begin{array}{c}\text { 8.Portfolio } \\
\text { II \% }\end{array}$ & 0.25 & 0.20 & -0.057 & $-{ }^{-} .147^{*}$ & -0.011 & $0.256^{* *}$ & $-{ }^{-} .322^{* *}$ & $-{ }^{-} .197^{* *}$ & -0.025 & 1 & & & & & \\
\hline $\begin{array}{c}\text { 9.Portfolio } \\
\text { III \% }\end{array}$ & 0.25 & 0.19 & -0.080 & $0.164^{*}$ & 0.037 & $-{ }^{-} .288^{* *}$ & $0.304^{\text {*** }}$ & $\begin{array}{l}- \\
0.142^{*}\end{array}$ & -0.053 & $0.585^{* *}$ & 1 & & & & \\
\hline $\begin{array}{c}\text { 10.Portfolio } \\
\text { IIII \% }\end{array}$ & 0.36 & 0.22 & $0.224^{* *}$ & 0.050 & 0.023 & $0.217^{* *}$ & $0.254^{* *}$ & $0.525^{* *}$ & $0.601^{* *}$ & $-{ }^{-} .370^{* *}$ & $0.261^{* *}$ & 1 & & & \\
\hline $\begin{array}{c}\text { 11.Debt } \\
\text { Asset ratio }\end{array}$ & 23.97 & 2.20 & $0.486^{* *}$ & $0.450^{* *}$ & 0.062 & $0.314^{* *}$ & $0.273^{* *}$ & $0.360^{* *}$ & $0.280^{* *}$ & -0.030 & -0.014 & $0.241^{* *}$ & 1 & & \\
\hline $\begin{array}{l}\text { 12.Ln total } \\
\text { assets; }\end{array}$ & 18.83 & 6.76 & -0.096 & 0.061 & -0.033 & -0.002 & 0.005 & 0.030 & -0.055 & 0.003 & -0.049 & 0.086 & 0.051 & 1 & \\
\hline 13.Age & 54.74 & 22.00 & $0.173^{* *}$ & $0.161^{*}$ & -0.025 & 0.057 & 0.105 & $0.138^{*}$ & $-{ }^{-} .143^{*}$ & -0.088 & 0.034 & $0.154^{*}$ & $0.694^{* *}$ & $0.197^{* *}$ & 1 \\
\hline
\end{tabular}

"Table V" reports the regression results about the influence of trademarks Portfolio on Enterprise Scale Elements measured by operating income. To verify the H1a-H1d, 5 models, each of which contains one of the independent variables, have been analyzed in turn. Multicollinearity was not a major concern in our results since correlation coefficients between the independent variables and the dependent variables are all lower than 0.5, and VIF values all are under 5. Model 1 reports the impact of all control variables $\left(R^{2}=0.293\right)$. Model 2 introduces Portfolio I to the regression model. This model reveals that the influence of Portfolio I on the operating income is not significant (t-value $=0.636$ ), which doesn't support the H1a. Model 3 introduces portfolio II as the independent variable, and the result of regression appears that no significant influence exists between Portfolio II and operating income ( $\mathrm{t}$-value $=0.618$ ), thus the $\mathrm{H} 1 \mathrm{~b}$ is not supported. Model 4 reveals that Portfolio III has a positive, significant influence on the operating incomes (t-value $=1.734$, $\mathrm{p}<0.1$ ), which support the H1c.The result of model 5 supports the H1d ( $\mathrm{t}$-value $=3.262, \mathrm{p}<0.01$ ) that more Portfolio IV mean enterprises have higher operating income.

TABLE V. REGRESSION RESULTS (DEPENDENT VARIABLE = SCALE ELEMENTS)

\begin{tabular}{|c|c|c|c|c|c|}
\hline & Model 1 & Model 2 & Model 3 & Model 4 & Model 5 \\
\hline Ln Total Assets; & $\begin{array}{l}0.693^{* *} \\
(8.978) \\
\end{array}$ & $\begin{array}{l}0.688^{* *} \\
(8.844)\end{array}$ & $\begin{array}{l}0.673^{* *} \\
(8.043) \\
\end{array}$ & $\begin{array}{l}0.655^{* *} \\
(8.172)\end{array}$ & $\begin{array}{l}0.594^{* *} \\
(7.281)\end{array}$ \\
\hline Age & $\begin{array}{l}-0.073 \\
(-1.293)\end{array}$ & $\begin{array}{l}-0.073 \\
(-1.281)\end{array}$ & $\begin{array}{l}-0.075 \\
(-1.312)\end{array}$ & $\begin{array}{l}-0.075 \\
(-1.331)\end{array}$ & $\begin{array}{l}-0.083 \\
(-1.487)\end{array}$ \\
\hline Debt Asset ratio & $\begin{array}{l}-0.294^{* *} \\
(-3.736)\end{array}$ & $\begin{array}{l}-0.289^{* *} \\
(-3.659)\end{array}$ & $\begin{array}{l}-0.282^{* *} \\
(-3.477)\end{array}$ & $\begin{array}{l}-0.277^{* * *} \\
(-3.510)\end{array}$ & $\begin{array}{l}-0.250^{* * *} \\
(-3.189)\end{array}$ \\
\hline Portfolio I & & $\begin{array}{l}0.035 \\
(0.636) \\
\end{array}$ & & & \\
\hline Portfolio II & & & $\begin{array}{l}0.037 \\
(0.618)\end{array}$ & & \\
\hline Portfolio III & & & & $\begin{array}{l}0.100^{\dagger} \\
(1.734)\end{array}$ & \\
\hline Portfolio IV & & & & & $\begin{array}{c}0.192^{* *} \\
(3.262)\end{array}$ \\
\hline$R^{2}$ & 0.293 & 0.294 & 0.294 & 0.302 & 0.324 \\
\hline
\end{tabular}


TABLE VI. REGRESSION RESULTS (DEPENDENT VARIABLE $=$ EFFICIENCY ELEMENTS)

\begin{tabular}{|c|c|c|c|c|c|c|c|c|c|}
\hline & Model 1 & Model 2a & Model 2b & Model 3a & Model 3b & Model 4a & Model 4b & Model 5a & Model 5b \\
\hline $\begin{array}{c}\text { Ln Total } \\
\text { Assets; }\end{array}$ & $\begin{array}{l}0.668^{* *} \\
(8.427)\end{array}$ & $\begin{array}{l}0.677^{* *} \\
(8.231)\end{array}$ & $\begin{array}{l}0.056^{* *} \\
(8.066)\end{array}$ & $\begin{array}{l}0.678^{* *} \\
(8.668)\end{array}$ & $\begin{array}{l}0.676^{* *} \\
(8.749)\end{array}$ & $\begin{array}{l}0.684^{* *} \\
(8.809)\end{array}$ & $\begin{array}{l}0.684^{* *} \\
(8.796)\end{array}$ & $\begin{array}{l}0.688^{* * *} \\
(8.520)\end{array}$ & $\begin{array}{l}0.688^{* * *} \\
(8.502)\end{array}$ \\
\hline Age & $\begin{array}{l}0.090 \\
(1.542)\end{array}$ & $\begin{array}{l}0.091 \\
(1.561)\end{array}$ & $\begin{array}{l}0.002 \\
(1.511)\end{array}$ & $\begin{array}{l}0.094 \\
(1.637)\end{array}$ & $\begin{array}{l}0.080 \\
(1.402)\end{array}$ & $\begin{array}{l}0.102 \\
(1.791)\end{array}$ & $\begin{array}{l}0.101 \\
(1.772)\end{array}$ & $\begin{array}{l}0.096 \\
(1.642)\end{array}$ & $\begin{array}{l}0.095 \\
(1.629)\end{array}$ \\
\hline $\begin{array}{l}\text { Debt Asset } \\
\text { ratio }\end{array}$ & $\begin{array}{l}-0.321^{* *} \\
(-3.971)\end{array}$ & $\begin{array}{l}-0.324^{* *} \\
(-3.984)\end{array}$ & $\begin{array}{l}-0.003^{* *} \\
(-3.969)\end{array}$ & $\begin{array}{l}-0.342^{* *} \\
(-4.279)\end{array}$ & $\begin{array}{l}-0.348^{* *} \\
(-4.403)\end{array}$ & $\begin{array}{l}-0.341^{* *} \\
(-4.304)\end{array}$ & $\begin{array}{l}-0.341^{* *} \\
(-4.303)\end{array}$ & $\begin{array}{l}-0.324^{* *} \\
(-4.020)\end{array}$ & $\begin{array}{l}-0.324^{* *} \\
(-4.010)\end{array}$ \\
\hline Portfolio I \% & & $\begin{array}{l}0.024 \\
(0.409)\end{array}$ & $\begin{array}{l}-0.038 \\
(-0.228)\end{array}$ & & & & & & \\
\hline $\begin{array}{c}\text { Portfolio } \\
\mathrm{I}^{2}{ }^{2}\end{array}$ & & & $\begin{array}{l}0.061 \\
(0.441)\end{array}$ & & & & & & \\
\hline $\begin{array}{c}\text { Portfolio } \\
\text { II \% }\end{array}$ & & & & $\begin{array}{l}-0.157^{* *} \\
(-2.793)\end{array}$ & $\begin{array}{l}-0.545^{* *} \\
(-3.413)\end{array}$ & & & & \\
\hline $\begin{array}{c}\text { Portfolio } \\
\text { II } \%^{2}\end{array}$ & & & & & $\begin{array}{l}0.413^{*} \\
(2.592)\end{array}$ & & & & \\
\hline $\begin{array}{c}\text { Portfolio } \\
\text { III \% }\end{array}$ & & & & & & $\begin{array}{l}0.190^{* *} \\
(3.418)\end{array}$ & $\begin{array}{l}0.126 \\
(0.727)\end{array}$ & & \\
\hline $\begin{array}{c}\text { Portfolio } \\
\text { III } \%^{2}\end{array}$ & & & & & & & $\begin{array}{l}0.067 \\
(0.389)\end{array}$ & & \\
\hline $\begin{array}{c}\text { Portfolio } \\
\text { IV \% }\end{array}$ & & & & & & & & $\begin{array}{l}-0.074 \\
(-1.258)\end{array}$ & $\begin{array}{l}-0.092 \\
(-0.480)\end{array}$ \\
\hline $\begin{array}{c}\text { Portfolio } \\
\text { IV } \%^{2}\end{array}$ & & & & & & & & & $\begin{array}{l}0.020 \\
(0.102)\end{array}$ \\
\hline$R^{2}$ & 0.255 & 0.255 & 0.256 & 0.279 & 0.300 & 0.291 & 0.291 & 0.260 & 0.260 \\
\hline
\end{tabular}

"Table VI" reports the regression results with regards to the influence of each trademarks Portfolio proportion on Enterprises Efficiency Elements, which are measured by operating profit margin (OPM). In the same way as above, this paper makes regression analysis of each variable separately. To explore whether there is a u-shaped relationship between independent variables and dependent variables, this paper adds the quadratic term of each variable into regression model. Model 1 reports the impact of all control variables, showing that total assets $(\mathrm{t}$-value $=8.472$, $\mathrm{p}<0.01)$ and debt asset ratio $(\mathrm{t}-\mathrm{value}=-3.791, \mathrm{p}<0.01)$ have $\mathrm{a}$ significant impact on OPM.

Model 2 tests the effect of the ratio of Portfolio I on the OPM, and the regression result reveals that Portfolio I \% have no significant effect on OPM (t-value $=0.409$ ). Thus $\mathrm{H} 2 \mathrm{a}$ is not supported.

$\mathrm{H} 2 \mathrm{~b}$ predicts the ratio of Portfolio II has a positive impact on OPM. But from the Model 3a and Model 3b, all the coefficients of Portfolio II \% are negative and significant $(\beta=-0.157, p<0.01)$, which contradicting to $H 2 b$. However, the effect of its squared term is positive and significant $(\beta=$ $0.413, \mathrm{p}<0.05)$. It reveals that Portfolio II \% has a U-shaped relationship with OPM. Take the partial derivative of the independent variable of the regression model, according to the unstandardized coefficients of the Portfolio II \%(-0.481) and Portfolio II $\%^{2}(0.495)$, when the partial derivative of the independent variable is zero, the turning point is calculated to be equal to approximate $48 \%$.

$\mathrm{H} 2 \mathrm{c}$ predicts that the ratio of Portfolio III has a positive effect on OPM. In Model 4a, the coefficient of Portfolio III $\%$ is positive and statistically significant $(\beta=0.190, p$ $<0.01)$. In Model $4 \mathrm{~b}$, the effect of its squared term is insignificant. Thus, $\mathrm{H} 2 \mathrm{c}$ is supported.

In the "Table VII", Model $4 \mathrm{a}$ and Model $4 \mathrm{~b}$ are used to verify that whether $\mathrm{H} 2 \mathrm{~d}$ is established. Regression results shows that there is no significant relationship between the ratio of Portfolio IV and OPM. Therefore, hypothesis $\mathrm{H} 2 \mathrm{~d}$ is not supported.

\section{TABLE VII. ANALYSIS OF HYPOTHESIS 1}

\begin{tabular}{|c|l|l|}
\hline H1 & \multicolumn{1}{|c|}{ result } & \multicolumn{1}{c|}{ Explanation } \\
\hline HIa & Non-significant & $\begin{array}{l}\text { The more main trademarks do not represent more operating income, which means the } \\
\text { correlation between the main trademark and the operating income in the main business is } \\
\text { not obvious. }\end{array}$ \\
\hline $\boldsymbol{H I b}$ & Non-significant & $\begin{array}{l}\text { The portfolio II is not significantly related to operating income, which means that the } \\
\text { more defensive trademarks do not represent more operating income. }\end{array}$ \\
\hline $\boldsymbol{H I c}$ & Significant & $\begin{array}{l}\text { Portfolio III has a positive correlation with operating income, indicating that the more } \\
\text { joint trademarks an enterprise has, the more operating income it will have. }\end{array}$ \\
\hline $\boldsymbol{H I d}$ & Significant & $\begin{array}{l}\text { Portfolio IV is positively correlated with operating income. It shows that the use (storage) } \\
\text { of non-principal trademarks in non-core business is conducive to the development of } \\
\text { diversified businesses to increase the enterprise's income. }\end{array}$ \\
\hline
\end{tabular}




\section{FURTHER EXPLANATION AND DISCUSSION}

\section{A. Relevant Discussion On Different Trademark Portfolios and Business Scale}

The effect of trademark portfolio on operating income is shown in "Table VIII".

Because the operating income represents the size of the business economy (Thuvarakan and Senthilmani, 2013). Therefore, the hypothesis of the relationship between the trademark portfolio to be certified and the size of the company's economy is as follows.

- The main trademark of the main business represents the enterprise's core brand. However, more than one core brand owned by a company does not mean that it can bring economies of scale to the company. It must adapt to the size of the business economy and market demand.

- The enterprise uses the main trademark for non-main business representatives to build a brand defense system (Berry and Seltman, 2007). However, there are many defensive trademarks, which is not necessarily conducive to expanding the economic scale of enterprises. For example, the well-known Coca-Cola brand, although trademark owners have registered on 32 kinds of goods, it is mainly used in beverages, and its well-known name is also wellknown for the beverage trademark, and registration on other commodities is protective (Farquhar and
Peter H,1989). For Coca-Cola, the registration of the Coca-Cola trademark outside the beverage does not have much impact on the scale of the company's expansion.

- H1c and H1d indicate that the storage or use of nonmain trademarks by enterprises in both the main and non-main businesses promotes the economic scale of the company. In general, this paper believe that a joint trademark is conducive to the development of diversified businesses, and the use of joint trademarks for goods of different qualities and grades will make it easier for consumers to identify the quality grade of goods and thus increase operating income(Guo,2006). However, H1d proves that not only the joint trademark, but also the trademark that is not related to the main business and irrelevant to the main trademark, will also help increase operating income and expand the economic scale of the company. Therefore, it seems that Chinese companies seem to be wasteful in registering non-related (necessary) trademarks in non-relevant (required) fields, but in reality they are conducive to enterprise growth.

\section{B. Discussion on the Relevance of Trademark Portfolio and Business Operation Efficiency}

"Table VIII" summarizes the effect of the trademark portfolio on the operating profitability of the company.

TABLE VIII. ANALYSIS OF HYPOTHESIS 2

\begin{tabular}{|l|l|l|}
\hline $\mathbf{H} 2$ & \multicolumn{1}{|c|}{ Result } & \multicolumn{1}{c|}{ Explanation } \\
\hline $\boldsymbol{H} 2 \boldsymbol{a}$ & Non-significant & $\begin{array}{l}\text { The proportion of the use of the main trademark in the main business to the total trademark portfolio is } \\
\text { not related to the operating profit margin. }\end{array}$ \\
\hline $\boldsymbol{H} 2 \boldsymbol{b}$ & $\begin{array}{l}\text { Has a U-shaped relationship } \\
\text { and the turning point was } \\
48 \% .\end{array}$ & $\begin{array}{l}\text { When Portfolio II / Total Portfolio's ratio is below 48\%, it is not conducive to the growth of operating } \\
\text { profit margin; but when the ratio reaches or exceeds } 48 \%, \text { it is conducive to the growth of operating } \\
\text { profit margin. }\end{array}$ \\
\hline $\boldsymbol{H} 2 \boldsymbol{c}$ & Significant & $\begin{array}{l}\text { The ratio of the use of non-main trademarks to the total trademark portfolio in the main business has a } \\
\text { positive relationship with the operating profit margin, which is conducive to improving the operating } \\
\text { profit margin. }\end{array}$ \\
\hline $\boldsymbol{H} 2 \boldsymbol{d}$ & Non-significant & $\begin{array}{l}\text { The proportion of the use of the non-main trademark in the non-main business to the total trademark } \\
\text { portfolio is not related to the operating profit margin. }\end{array}$ \\
\hline
\end{tabular}

Because profit is the most fundamental source and driving force for the development of an enterprise's economy, the scale of growth without support for profit growth is a growth factor that contains bubbles, so the operating profit margin index represents the economic efficiency and growth quality of the enterprise (Zhao\&Ren, 2015).

- Enterprises often use strong trademarks for their main business. Ake (2012) pointed out: "The key to building a strong brand is to establish differentiated perceptions and improve the brand image." Clearly, the number of main trademarks used in the main business is not an effective measure to build a strong brand. Therefore, enterprises must be cautious when deciding on the number of strong brands.

- In order to prevent the brand's image and uniqueness from being diluted (Kuenzler,2017), enterprises often register (use) the main trademark in non-main business. How to effectively combine the defense function of a trademark with the promotion of economic efficiency, enterprises must pay attention to the proportion of such trademark portfolios in the total trademark portfolio. Because less than $48 \%$ is often not conducive to improving the economic efficiency of enterprises, and only if it meets or exceeds $48 \%$, enterprises can improve economic efficiency.

- The use of non-master trademarks in the main business is the necessary layout of the trademark when the company constructs a joint trademark or brand alliance. It is conducive to the development of diversified businesses, and the use of joint trademarks for goods of different qualities and grades will make 
it easier for consumers to identify the quality grades of goods (Guo,2006). Therefore, this type of trademark portfolio is conducive to improving the economic efficiency of enterprises.

- The proportion of non-main trademarks used in nonmain business in the trademark portfolio is not related to the economic efficiency of the company. Therefore, companies should not choose this method to promote brands.

\section{The Enlightenment of the Trademark Layout}

The above analysis shows that enterprise's trademark portfolios is closely related to enterprise performance. In order to ensure a positive relationship between an enterprise's trademark portfolio and enterprise performance, the enterprise needs three key steps:

Identifying trademarks and business boundaries.

The enterprise should open the trademark" black box" based on the brand vision and positioning, identifying the products and services that the brand should provide and the interests and needs that should be met. The trademark is divided into main trademark and non-main trademark; the business scope is divided into main business and non-main business.

1) Layout enterprise's leading brand portfolio: In order to implement differentiated strategies and centralized strategies to enhance the competitiveness of enterprises(Porter,1998), an enterprise should place its leading brand on the main trademark applicable to its main business, and the number of such trademark combinations cannot be dispersed but should be concentrated.

2) Determine brand extension method: First, determine the main trademark expansion opportunities. It is generally believed that brand extension cannot be excessive(Keller,2014), but our analysis shows that the use of a main mark in non-main business does not mean the pursuit of quantity. The key is to look at the ratio of this type of mark portfolio to all trademark combinations of the company when the ratio reaches or exceeds. At $48 \%$, it will help improve enterprise performance.

Second, identify non-main trademark expansion opportunities. The use of non-main trademarks in the main business will help improve enterprise performance. However, the use of non-main trademarks in non-main business is only helpful for expanding the scale of enterprises, but it is not conducive to improving the economic efficiency of enterprises. Therefore, enterprises should be cautious in selecting such trademark combinations.

\section{CONCLUSION AND OUTLOOK}

\section{A. Conclusions}

First, our research opened a trademark "black box", creatively constructed a trademark portfolio model, empirically analyzed the relationship between the portfolio of Chinese listed companies and enterprise performance, and empirically analyzed the a certain degree of rationality of the Chinese enterprise's trademark registration volume ranking first in the world. Through the trademark portfolio model, this paper has also found the path of the enterprise's trademark layout, which indicates the direction for enterprises to build brand portfolios, improve enterprise performance, and increase competitiveness.

Second, through empirical research, this paper further confirms the theoretical basis for scholars to enhance the competitiveness of enterprises, and the actual use of these theories to guide enterprise trademark portfolio. For example, through the differentiation strategy and the centralized strategy, Porter(1998) proposed to realize the competitive advantage of the enterprise. In the application of trademark portfolio, the above strategy reflects that the use of the main trademark on the main products should only be centralized and should not be dispersed.

Third, the research has also broken the scholars' longstanding understanding of the trademark (brand) strategy. For example, Keller (2014) believes that enterprises must control the number of brands and their brands must not be excessive. However, our research shows that the enterprise brand layout is not simply a quantitative issue, but depends on the boundaries of the brand layout. Even the use of nonprincipal trademarks in non-core businesses that this paper generally considers irrelevant, does not necessarily have an adverse effect on enterprise performance, and in turn, it also helps enterprises develop economies of scale.

Fourth, this paper has further expanded the thinking of the trademark (brand) strategy study. The results show that the use of non-main trademarks in the main business is conducive to improving enterprise performance; when nonmain trademarks are used in non-core business to meet certain conditions, it will help improve enterprise performance.

\section{B. Limitations and future research}

Our study is subject to some limitations, which also provides a further extended path for the future suggest interesting avenues for future research. First, The data sample selected in this paper is a listed company in China. This type of enterprise is usually a normal operating enterprise and is a larger enterprise. The conclusions of this paper are also applicable only to such enterprises. However, it should be noted that in China, another major player in registered trademarks is SMEs or non-regulated enterprises. Whether this paper's conclusion is applicable to such enterprises is still unknown.

Second, this paper collected trademark data from 10045 enterprises. It is also possible to further analyze the relationship between the trademark portfolio and the enterprise's performance based on the industry to which the enterprise belongs and the size of the enterprise's economy, so that the results of the data analysis are more instructive.

Third, this study uses the enterprise's operating income and operating profit margin as indicators of enterprise performance. However, this paper can also use the 
classification index system for the evaluation of enterprise brand competitiveness mentioned in some literature references (Zhang et.al, 2011) to more fully demonstrate the relationship between trademark portfolio and enterprise performance and even enterprise competitiveness.

\section{REFERENCES}

[1] Ake, David. Create a Strong Brand.Beijing: Machinery Industry Press, 2012:18.

[2] Barnes, David W.A New Economics of Trademarks.Northwestern Journal of Technology and Intellectual Property,2006(5):21-67.

[3] Bergh, Van den, Jeroen CJM, Harmen Verbruggen.Spatial Sustainability, Trade and Indicators: An Evaluation of the "Ecological Footprint'.Ecological Economic,1999(29):61-72.

[4] Berry, Leonard L., Kent D.Seltman.Building a strong services brand: Lessons from Mayo Clinic.Business Horizons,2007(3): 199-209.

[5] Besen,Stanley M., Leo J. Raskind.An Introduction to the Law and Economics of Intellectual Property.Journal of Economic Perspectives.1991,5 (1): 3-27.

[6] Block, Joern H.,Geertjan De Vries,Jan H.Schumann, PhilippSandnere. Trademarks and Venture Capital Valuation.Journal of Business Venturing,2014(4):525-542.

[7] Brexendorf Tim Oliver,Barry Bayus, Kevin Lane Keller. Understanding the Interplay between Brand and Innovation Management: Findings and Future Research Directions.Journal of the Academy of Marketing Science.2015(43): 548-557.

[8] Chen, Mingchen,Shuju Cheng and Yuhchang Hwang.An empirical investigation of the relationship between intellectual capital and firms' market value and financial performance.Journal of intellectual capital, 2005(6):159-176.

[9] Chiriac, Silviu C.V.Considerations Regarding the Evolution of the Liquidity and Solvency Indicators of the Most Important Romanian HORECA Companies in the Period 2010-2013.Procedia Economics and Finance, 2015(32):833-840.

[10] Crass, Dirk,Dirk Czarnitzki and Andrew Toole.The Dynamic Relationship between Investments in Brand Equity and enterprise Profitability: Evidence Using Trademark Registrations.ZEW - Centre for European Economic Research Discussion Paper 2016(April):1-35.

[11] Datta, Hannes, Kusum L. Ailawadi, Harald J. van Heerde.How Well Does Consumer-Based Brand Equity Align with Sales-Based Brand Equity and Marketing-Mix Response?Journal of Marketing, 2017(5):1-20

[12] Dresden, Matthew.Does China Have Too Many Trademarks? China Business, September 11,2017.

[13] Fairfield, Patricia M., Teri Lombardi Yohn, Using Asset Turnover and Profit Margin to Forecast Changes in Profitability.Review of Accounting Studies,2001(6):371-385.

[14] Farquhar, Peter H.Managing Brand Equity.Marketing Research, 1989(3):24-33.

[15] Freeman, Chirs and Luc Soete.The Economics of Industrial Innovation. Oxford:Taylor \&Francis Group, 1997:91.

[16] Guo, Xiushen.enterprise trademark strategy.Beijing:People's Publishing House, 2006:282.

[17] Heath, Davidson, Christopher Mace.What's a Brand Worth? Trademark Protection, Profits and Strategy, 2017.https://ssrn.com/abstract $=2798473$ http://dx.doi.org/10.2139/ssrn.2798473.

[18] Huang, Jiangwei.A Review of Brand Valuation Method.Journal of Service Science and Management, 2015(8): 71-76.

[19] Ishan, Zahira Mohd, Norrezan Noordin.Capitalising on Income Approach as Trademark Valuation for Entrepreneurs. Pertanika Journal of Social Sciences \& Humanities. Special Issue Management \& Marketing,2015(3):147-160.
[20] Ishan, Zahira Mohd, Norrezan Noordin. Capitalising on Income Approach as Trademark Valuation for Entrepreneurs.Pertanika Journal of Social Sciences \& Humanities ,2015(23):147-160.

[21] Kaplan, Robert S., David Norton.The Balanced Scorecard:Measures that Drive Performance.Harvard Business Review , 1992(1): 71-79.

[22] Kaplan, Robert S., David P.Norton.Putting the Balanced Scorecard to Work.Massachusetts:Human Resource Development Press, 1995:88.

[23] Keller, Kevin Lane, M.G. Parameswaran, Isaac Jacob. Strategic Brand Management: Building, Measuring, and Managing Brand Equity. Noida:Pearson Education India,2011:231.

[24] Keller, Kevin Lane.Brand Synthesis: The Multidimensionality of Brand Knowledge.Journal of Consumer Research,2003(5):595-600.

[25] Kuenzler, Adrian.Dilution Law, Vertical Agreements, and the Construction of Consumption.Oxford Journal of Legal Studies, 2017(1): 75-104.

[26] Liang, Xiaolin, Maozai Tian.An Empirical Analysis of the Total Assets and Operating Income of Listed Companies in China.Mathematics Practice and Understanding,2016(5):22-46.

[27] Mehrazeen, Ali Reza, Omid Froutan, Navid Attaran.Establishing the Relationship between Trademark Valuation and Firm Performance: Evidence from Iran.International Journal of Economics and Finance,2012(6):181-186.

[28] Mills, John, Jeanne H.Yamamura. The Power of Cash Flow Ratios.Journal of Accountancy,1998(4): 53-55.

[29] Modigliani, Franco, Merton H. Miller.The Cost of Capital, enterprise Finance and the Theory of Investment.The American Economic Review, 1958(3):261-297

[30] Mortanges, CharlesPahud de, Allardvan Riel.Brand Equity and Shareholder Value.European Management Journal,2003(21):521-527.

[31] Muhammad, Magaji Abubakar.An Investigation on the Performance of Operating Profit Margin of Privatized SOEs.International Journal of Academic Research in Business and Social Sciences, 2016(6):221227.

[32] Ness, J.A., Cucuzza T.G. Tapping the Full Potential of ABC.Harvard Business Review.1995(4):130-138.

[33] Newey, Lance R., Shaker A. Zahra. The Evolving Firm: How Dynamic and Operating Capabilities Interact to Enable Entrepreneurship.British Academy of Management,2009(20):81-100.

[34] Nguyen, Xuan Thao.The World's Trademark power house: A Critique of China's New Trademark Law.Seattle U. L. Rev,(20162017):901-909.

[35] Patten, Ronald J.,Charlene D. Patten, Procter \& Gamble.Some Financial Measures for the Busy Small Business Owner.Review of Business Information Systems,2014(18):12-19.

[36] Porter, Michael E.Competitive Strategy.New York:Free Press, 1998:39.

[37] Smith, Gordon V., Susan M. Richey.Trademark Valuation-A Tool for Brand Management(Second Edition).WILEY,2013:58.

[38] Wan, Peng, Xiaohui Qu.Government Control, Revenue Manipulation, and Operating Income Program Levels: Empirical Evidence from China's Capital Markets. Contemporary Finance,2012(2):109-120.

[39] Wilkins, Mira.The Neglected Intangible Asset: The Influence of the Trade Mark on the Rise of the Modern enterprise.Journal Business History ,2006(7):66-95

[40] Wu, Pengshan. Intellectual property rights are protected in China.Beijing:Law Press in China,2009:139.

[41] Xiao, Yangao. enterprise Intellectual Property Capability and Competitive Advantage.Beijing:Intellectual Property Publishing House, 2010:90.

[42] Yohe, Gary, Richard S.J.Tol.Indicators for Social and Economic Coping Capacity-Moving toward a Working Definition of Adaptive Capacity.Global Environmental Change,2002(12):25-40.

[43] Zhang, Huishan.From Tools to Property: Historical Changes in the Concept of Trademarks.Intellectual property,2016(3):61-64.

[44] Zhang, Shixian,Shiwei Yang,Hongda Zhao, Haiou Li.China Enterprise Brand Competitiveness Index System-Theory and 
Practice. Beijing: Economy \&Management Publishing House, 2011:116.

[45] Zhao, Qing, Guangyu Ren.Seeing the Leading Force of High-tech Enterprises on Economy from the Perspective of Operating Profit Rate: Taking Huawei as an Example.Modern Business,2015(5):62-64.

[46] Zheng, Chengsi.Legal Issues in the Evaluation of Intellectual Property Value.China Soft Science,1998(4):102-105.

[47] Zubarev, I.S. Influence of profitability of the enterprise on.International Journal of Professional Science,2017(4):92-94. 